Artikel Penelitian

\title{
Uji Efektivitas Antibakteri Ekstrak Aloe vera Terhadap Pertumbuhan Escherichia coli Secara In Vitro.
}

\author{
Nova Suryati ${ }^{1}$, Elizabeth Bahar ${ }^{2}$, IImiawati $^{3}$
}

\begin{abstract}
Abstrak
Lidah Buaya (Aloe vera) merupakan salah satu tanaman yang digunakan sebagai obat. Lidah buaya mempunyai berbagai khasiat, salah satunya sebagai antibakteri. Adanya efek antibakteri pada lidah buaya karena lidah buaya mengandung senyawa antibakteri seperti saponin, tannin dan flavonoid. Penelitian sebelumnya menunjukkan bahwa ekstrak lidah buaya dapat menghambat pertumbuhan bakteri gram positif dan gram negatif. Tujuan penelitian ini adalah mengetahui efek antibakteri ekstrak lidah buaya terhadap pertumbuhan Escherichia coli. Ekstrak etanol lidah buaya dibuat dengan menggunakan lidah buaya segar dalam lima konsentrasi $(6,25 \%, 12,5 \%$, $25 \%, 50 \%$ dan $100 \%$ ) yang diuji daya hambatnya. Penelitian ini menggunakan bakteri Escherichia coli yang dibiakkan dalam tiga agar dan diuji menggunakan metode difusi. Didapatkan bahwa tidak terdapatnya daerah bening disekitar cakram yang telah mengandung ekstrak lidah buaya pada semua konsentrasi. Simpulan penelitian ini adalah ekstrak aloe vera tidak mempunyai aktivitas antibakteri terhadap Escherichia coli.
\end{abstract}

Kata Kunci: lidah buaya, Escherichia coli, ekstrak

\begin{abstract}
,Aloe vera has several health benefits such as antibacterial activity. Aloe vera has antibacterial substances, such as saponins, tannins and flavonoids. Previous studies indicate that Aloe vera extract has inhibitory activity against the growth of gram positive and negative bacteria. The objective of this study was to determine the antibacterial activity of Aloe vera extract against the growth of Escherichia coli. Aloe vera ethanol extract was prepared from fresh plants in five concentration $(6.25 \%, 12.5 \%, 25 \%, 50 \%$ and 100\%). The experiment was performed on the growth of Escherichia coli in three agar replicates by using disc diffusion method. Results showed that there were no clear zones around disc of Aloe vera extract-infused at all concentration. The conclusion is Aloe vera extract does not have antibacterial activity against Escherichia coli at the studied condition.
\end{abstract}

Keywords: Aloe vera, Escherichia coli, extract

Affiliasi penulis: 1. Prodi Profesi Dokter FK Unand (Faklutas Kedokteran Universitas Andalas Padang) 2. Bagian Mikrobiologi FK Unand, 3. Bagian Farmakologi FK Unand

Korespondensi: Nova Suryati, Email: novasuryati@gmail.com Telp: 085766384858

\section{PENDAHULUAN}

Tanaman lidah buaya (Aloe vera) merupakan tanaman Lliliaceae yang mempunyai sejumlah spesies yang berbeda. Diantara spesies ini, hanya satu jenis yang lazim digunakan sebagai tanaman obat sejak ribuan tahun yang lalu yaitu Aloe vera barbadensis. ${ }^{1}$
Habitat aslinya berasal dari kepulauan Canary, sebelah barat Afrika dan diperkirakan masuk Indonesia pada abad ke-17. ${ }^{2}$ Sebagai tanaman hias, tanaman ini memang tampak indah karena keunikan daunnya yang tebal dan berduri, namun seiring dengan kemajuan ilmu pengetahuan dan teknologi, pemanfaatan lidah buaya berkembang sebagai bahan baku industri farmasi, kosmetika serta sebagai bahan makanan dan minuman kesehatan. Tanaman ini juga mempunyai khasiat yang baik untuk kesehatan karena mengandung antibakteri. ${ }^{3}$ 
Penelitian tentang efektifitas lidah buaya sebagai antibakteri telah banyak dilakukan. Penelitian yang dilakukan oleh Pandey dan Avinash menunjukkan bahwa ekstrak lidah buaya mampu menghambat pertumbuhan bakteri gram positif (Staphylococcus aureus dan Enterococcus bovis) dan gram negatif (Proteus vulgaris, Proteus mirabilis, Pseudomonas aeruginosa dan Klebsiella pneumonia). ${ }^{4}$ Efektifitas lidah buaya terhadap bakteri gram positif mempunyai zona hambat lebih besar dibandingkan bakteri gram negatif. ${ }^{5}$ Menurut Nur Alim Natsir, ekstrak daun lidah buaya pada konsentrasi $25 \%, 30 \%$ dan $35 \%$ mampu menghambat pertumbuhan bakteri Staphylococcus aureus dengan daya hambat tertinggi sebesar $1,6 \mathrm{~mm}^{6}{ }^{6}$ Lidah buaya juga terbukti efektifitasnya dalam membunuh dan mengeliminasi pertumbuhan bakteri Staphylococcus aureus, Bacillus subtilis, Proteus vulgaris, Candida albicans, dan Penicillinum sps. Efek antibakteri lidah buaya disebabkan karena terdapatnya komponen bioaktif dalam ekstrak lidah buaya. ${ }^{7}$

Sebagai antibakteri, lidah buaya mengandung zat-zat aktif seperti saponin tannin dan flavonoid. Saponin merupakan zat alkaloid yang dapat merusak asam (DNA dan RNA) bakteri. Tannin sebagai antibakteri berkerja dengan menginaktivasi adhesin sehingga bakteri tidak dapat menempel pada sel epitel hospes. Lidah buaya juga mengandung flavonoid yang akan mengakibatkan lisis dan menghambat proses pembentukan dinding sel. Mekanisme diatas menyebabkan lidah buaya dapat membunuh ataupun menghambat pembentukan bakteri. ${ }^{8}$

Escherichia coli merupakan bakteri gram negatif enterik (Enterobactericeae) yaitu kuman flora normal yang ditemukan dalam usus besar manusia. Bakteri ini bersifat patogen apabila berada diluar usus, yaitu lokasi normal tempatnya berada dan tempat lain yang jarang ditinggali oleh bakteri ini. Escherichia coli sering menimbulkan infeksi pada saluran kemih, saluran empedu dan tempat-tempat lain di rongga perut. Escherichia coli juga merupakan penyebab diare dan infeksi saluran kemih. ${ }^{9}$
Belum adanya penelitian efek antibakteri ekstrak lidah buaya terhadap pertumbuhan bakteri Escherichia coli, maka perlu diteliti apakah ekstrak daun lidah buaya juga berkhasiat sebagai antibakteri terhadap bakteri Escherichia coli.

\section{METODE}

Penelitian ini telah dilakukan di laboratorium Mikrobiologi Fakultas Kedokteran Universitas Andalas Padang pada bulan November 2014 sampai Agustus 2015. Jenis penelitian adalah eksperimental dengan tiga kali pengulangan menggunakan metode difusi. Sampel yang digunakan adalah bakteri Escherichia coli. Variabel bebas adalah ekstrak lidah buaya. Variabel terikat adalah pertumbuhan bakteri Escherichia coli. Penelitian uji antibakteri dilakukan di Laboratorium Mikrobiologi Fakultas Kedokteran Unand dan ekstraksi lidah buaya dilakukan di Laboratorium Kimia Organik Bahan Alam FMIPA Universitas Andalas

\section{HASIL}

Penelitian dilakukan dengan menggunakan lima cakram berisi Aloe vera dengan konsentrasi $6,25 \%, 12,5 \% 25 \%, 50 \%, 100 \%$. yang direndam selama 15 menit. Sebanyak 1-2 ose dari biakan bakteri uji yang telah dikultur dan tumbuh disuspensikan dengan menggunakan $\mathrm{NaCl}$ 0,9\% sampai diperoleh kekeruhan yang sama dengan standard Mc.Farland 0,5. Setelah itu disiapkan cawan petri berisi Mueller Hinton Agar yang akan digunakan sebagai media uji bakteri. Selanjutnya menggunakan lidi kapas steril, suspensi kuman Escherichia coli disebar merata pada medium Mueller Hinton Agar sampai permukaannya tertutupi.Kemudian cakram kosong yang telah direndam bahan uji diletakkan disetiap area pada cawan petri. Setelah itu cawan petri diinkubasi di dalam inkubator pada suhu $37^{\circ} \mathrm{C}$ selama 24 jam. Setelah 24 jam, cawan-cawan petri tersebut dikeluarkan dari inkubator dan dilihat daya hambat yang terjadi pada setiap cakram dan diukur zona bening yang terbentuk dengan menggunakan kaliper. 
Tabel 1. Hasil uji daya hambat lidah buaya terhadap pertumbuhan Escherichia coli

\begin{tabular}{lcccc}
\hline Perlakuan & \multicolumn{3}{c}{ Cawan Petri } & \multicolumn{2}{c}{ Rata-rata } \\
& $\mathbf{1}$ & $\mathbf{2}$ & $\mathbf{3}$ & $\mathbf{( m m )}$ \\
\hline Kontrol negatif & - & - & - & - \\
Ekstrak 6,25\% & - & - & - & - \\
Ekstrak 12,5\% & - & - & - & - \\
Ekstrak 25\% & - & - & - & - \\
Ekstrak 50\% & - & - & - & - \\
Ekstrak 100\% & - & - & - & - \\
Amoksisilin & 14 & 15 & 13 & 14 \\
Kloramfenikol & 16 & 16 & 17 & 16,33 \\
\hline
\end{tabular}

Pada tabel diatas didapatkan hasil bahwa ekstrak lidah buaya dalam berbagai konsentrasi tidak mempunyai efek antibakteri terhadap Escherichia coli. Hal ini dibuktikan dengan tidak terdapatnya diameter zona hambat disekitar cakram yang mengandung esktrak lidah buaya. Setelah dilakukan pengulangan sebanyak tiga kali, tetap tidak ditemukannya daerah bebas kuman disekitar cakram disc. Aquades sebagai kontrol negatif juga tidak menghasilkan daya hambat terhadap Escherichia coli. Sedangkan Amoksisilin dan kloramfenikol sebagai kontrol positif memberikan daya hambat terhadap pertumbuhan Escherichia coli dengan zona hambat rata-rata $14 \mathrm{~mm}$ dan $16,33 \mathrm{~mm}$.

\section{PEMBAHASAN}

Penelitian yang telah dilakukan mengenai efek antibakteri ekstrak lidah buaya terhadap Escherichia coli didapatkan hasil bahwa ekstrak lidah buaya tidak mempunyai efek antibakteri terhadap Escherichia coli. Hal ini terbukti dengan tidak terdapatnya diameter zona hambat pada cakram. Tidak terdapatnya zona hambat kemungkinan dipengaruhi oleh jenis lidah buaya, metode yang dipakai dan bakteri yang digunakan dalam penelitian.

Perbedaan jenis lidah buaya mempengaruhi ada atau tidaknya daya hambat lidah buaya terhadap Escherichia coli. Jenis lidah buaya sangat menentukan jumlah kandungan zat antibakteri yang terkandung di dalam lidah buaya tersebut. Adanya variasi biologis dari masing-masing lidah buaya akan mempengaruhi jumlah bahan aktif antimikroba. Lidah buaya yang tumbuh di daerah $\mathrm{X}$ dapat memiliki kandungan yang berbeda dengan lidah buaya yang tumbuh di daerah $\mathrm{Y}{ }^{8}$

Penelitian yang dilakukan Agarry et al dengan menggunakan lidah buaya yang berasal dari Nigeria merupakan tempat yang baik untuk tanaman lidah buaya karena lidah buaya cocok ditanam pada daerah bersuhu tinggi, sedangkan lidah buaya pada penelitian ini berasal dari kota Padang yang memiliki iklim, suhu dan keadaan tanah yang berbeda, sehingga juga mempengaruhi efek antibakterinya. ${ }^{10}$

Lidah buaya yang digunakan ini berasal dari tanaman yang ditanam di pekarangan rumah, sehingga lidah buaya yang digunakan juga dapat dipengaruhi oleh faktor-faktor yang tidak terkontrol seperti pupuk, penyiraman, pencahayaan dan lain-lain. Tidak terkontrolnya faktor-faktor pertumbuhan tersebut akan berpengaruh terhadap jumlah zat antibakteri yang terdapat pada sampel. Jika jumlah zat antibakteri rendah maka konsentrasi zat aktif tersebut akan rendah sehingga tidak mampu mampu merusak membran sel dan menganggu proses fisiologis sel. Hal ini menyebabkan tidak timbulnya zona hambat terhadap pertumbuhan kuman. ${ }^{11}$

Perbedaan metode juga berpengaruh terhadap hasil penelitian. Hal ini bisa disebabkan karena beberapa faktor antara lain yaitu proses perendaman cakram didalam esktrak Aloe vera. Kemungkinan perendaman yang terlalu cepat berpengaruh terhadap tidak terdapatnya daya hambat pada cakram. Pengambilan Escherichia coli dengan ose dan disuspensikan dengan $\mathrm{NaCl} \quad 0,9 \%$ mungkin tidak tersuspensi dengan sempurna sehingga mempengaruhi hasil penelitian. Faktor penggoresan Escherichia coli yang tidak merata pada Agar Mueller Hinton juga dapat menyebabkan tidak terjadinya efek antibakteri disekeliling cakram tersebut.

Proses pembuatan ekstrak juga berpengaruh terhadap kandungan zat aktif pada lidah buaya. Proses pencucian lidah buaya dengan menggunakan air untuk menghilangkan kotoran seperti tanah dan benda asing lainnya akan mempengaruhi kandungan zat yang terdapat di dalam lidah buaya. Pencucian bahan simplisia yang mudah larut dalam air harus 
dalam waktu sesingkat mungkin karena dapat menyebabkan berkurang atau hilang zat yang diperlukan. Irisan yang terlalu tipis juga dapat menyebabkan perubahan komposisi zat aktif yang terdapat dalam Aloe vera karena terjadinya penguapan. ${ }^{12}$

Perbedaan hasil yang ditemukan juga disebabkan karena bagian lidah buaya yang digunakan dalam penelitian. Penelitian ini menggunakan whole extract yaitu estrak lidah buaya secara utuh tanpa memisahkan setiap bagian daun. Pada penelitian Aggarry, memisahkan bagian gel dan kulit daun lidah buaya karena gel mengandung komponen antibakteri sehingga sifat antibakteri lebih besar, tetapi tidak efektif untuk kulit daun. ${ }^{10}$ Hal ini dibuktikan dengan beberapa penelitian sebelumnya yang menggunakan gel lidah buaya, sehingga diperoleh zona hambat dari penelitian tersebut. Pada penelitian lain, ekstrak gel lidah buaya memiliki efektivitas daya hambat terhadap Methicillin Resistant Staphylococcus aureus (MRSA) secara in vitro. ${ }^{8}$

Kemungkinan penyebab lain adalah interaksi antara senyawa aktif antibakteri yang terkandung di dalam lidah buaya dan kandungan senyawa lain yang dapat mempengaruhi kerja antibakteri tersebut. Senyawa lain akan menganggu penetrasi senyawa aktif ke dalam dinding sel bakteri sehingga tidak efektif untuk menghambat bakteri tersebut. Terdapatnya zona hambat juga bergantung beberapa faktor seperti kecepatan difusi, ukuran molekul, stabilitas bahan antibakteri, sifat media agar yang digunakan, jumlah organisme yang diinokulasi, kecepatan tumbuh bakteri, konsentrasi bahan kimia dan kondisi saat inkubasi. ${ }^{13}$

Perbedaan strain bakteri menyebabkan perbedaan enzim dan zat lainnya yang dihasilkan oleh bakteri. perbedaan enzim memberikan efek yang berbeda terhadap zat antibakteri yang terkandung di dalam lidah buaya. Enzim yang dihasilkan oleh bakteri dapat menghancurkan atau merusak zat antibakteri tersebut. ${ }^{9}$ Bakteri mensintesis enzim yang dapat mengubah zat aktif menjadi tidak aktif sehingga bakteri resisten terhadap zat antibakteri. Salah satu zat aktif yang terdapat didalam lidah buaya adalah gugus glikosida. Bakteri Escherichia coli yang telah resisten mempunyai enzim inaktivator aminoglikosida sehingga aminoglikosida gagal penetrasi ke dalam bakteri. Kandungan lainnya yaitu saponin. Penelitian oleh Soetan et al (2006) bahwa saponin dari lidah buaya efektif menghambat bakteri Gram positif namun tidak efektif menghambat Gram negatif. ${ }^{14}$

Penelitian sebelumnya membuktikan bahwa ekstrak lidah buaya mampu menghambat bakteri Gram positif seperti Streptococcus dan Staphylococcus. Bakteri Escherichia coli merupakan bakteri Gram negatif yang memiliki lapisan-lapisan dinding sel yang lebih kompleks dibandingkan bakteri Gram positif sehingga senyawa antibakteri Aloe vera lebih sulit berdifusi ke dalam membran sel bakteri Gram negatif. Bakteri Gram negatif memiliki 3 lapisan yaitu lipopolisakarida, protein dan fosfolipid. Pada membran terluar terdapat porin yang bersifat hidrofilik. Sedangkan ekstrak lidah buaya bersifat hidrofobik. Hal ini menyebabkan komponen ekstrak sukar masuk ke dalam sel bakteri. ${ }^{15}$

Manfaat lidah buaya dalam menyembuhkan penyakit infeksi kemungkinan lebih banyak dengan peningkatan imun host daripada efek antibakteri yang dimiliki oleh lidah buaya. Acemanan juga meningkatkan produksi IL2 dan MHC kelas II sehingga fungsi limfosit ThCD4+ menjadi optimal dan dapat fagositosis bakteri dan sel yang terinfeksi. Terdapat juga efek sitolitik dari sel Naturral Killer (NK) dalam mengeliminasi bakteri dan sel yang terinfeksi. ${ }^{16}$

\section{SIMPULAN}

Ekstrak Aloe vera pada penelitian ini tidak mempunyai daya hambat terhadap Escherichia coli.

\section{DAFTAR PUSTAKA}

1. Johnson M, Joy Renishyeya JM, Beaulah N. Antibacterial and antifungal activity of Aloe vera gel extract. International Journal of Biomedical and Advance Research. 2012;03:03.

2. Arifin J. Intensif budidaya lidah buaya. Yogyakarta: Pustaka Baru Press; 2015.

3. Surjushe A, Vasani R, Saple GD. Aloe vera short review. Indian Journal Dermatology. 2008; 53(4):163-6.

4. Pandey R, Avinash M. antibacterial activities of crude extract of Aloe barbadensis to clinically 
isolated bacterial pathogens. Application Biochemistry Biotechnology. 2010;160;1356-61.

5. Lawrence $R$, Tripathi $P$, Jeyakumar E. Isolation, purification and evaluation of antibacteial agents from Aloe vera. Brazilian Journal of Microbiology. 2009;40(4):1-4.

6. Alim N. Pengaruh ekstrak daun lidah buaya sebagai penghambat pertumbuhan bakteri Staphylococcus aureus. Ambon:FMIPA Universitas Pattimura; 2013.

7. Irshad SM, Butt M, Younus $\mathrm{H}$. In-vitro antibacterial activity of Aloe barbadensis Miller. International Research Journal of Pharmaceuticals. 2011;1(2);59-64.

8. Noorhamdani AS, Hidayati S, Rahmawati V. Uji efektivitas ekstrak gel lidah buaya terhadap methicillin resistant Staphylococcus aureus secara in vitro (skripsi). Malang: Fakultas Kedokteran Universitas Brawijaya; 2010.

9. Jawetz E, Melnick J, Adelberg EA. Mikrobiologi kedokteran, (terjemahan). Edisi ke-25. Jakarta: EGC; 2005.

10. Agarry OO, Olaleye MT, Bellomichael. Comparative antimicrobial activities of Aloe vera gel and leaf. African Journal of Biothechnology. 2005;12(4):1413-14.

11. Cowan MM, 1999. Plant product as antimicrobial agent. Clinical Microbiology Reviews. 1999;12(4): 564-82.

12. Badan Pengawas Obat dan Makanan Republik Indonesia. Pedoman teknologi formulasi sediaan berbasis ekstrak. Jakarta: 2013.

13. Iriano A. Efektivitas antibakteri infusum Aloe vera terhadap porphyromonas gingivalis in vitro (skripsi). Jakarta: Fakultas Kedokteran Gigi Universitas Indonesia; 2008.

14. Soetan K, Oyekunie MA, Aiyelaagbe OO, Fafunso MA. Evaluation of antimicrobial activity of saponins extract of sorghum bicolor moench. African Journal of Biotechnology. 2006;4;2405-7.

15. Iskandar Y, Rusmiati D, Rusma RD. Uji efektivitas antibakteri ekstrak etanol rumput laut terhadap bakteri Escherichia coli dan Bacillus cereus (skripsi). Bandung: Fakultas MIPA Universitas Padjajaran; 2010.

16. Lee JK, Yuna MK, Lee CK. Acemannan purified from Aloe vera induces phenotypic and functional maturation of immature dendritic cells. International Journal of Immunopharmacol. 2001;7(1):1275-84. 